\title{
Ano Internacional da Química/IYC 2011 - A SPQ em Acção
}

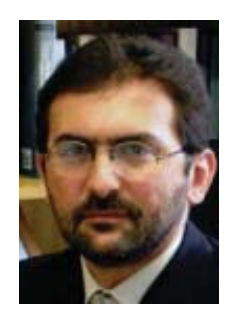

Desde o início da iniciativa Ano Internacional da Química 2011 (IYC 2011) que a Sociedade Portuguesa de Química (SPQ) se assumiu como o representante nacional desta acção global. Comprometeu-se desde logo com os objectivos de promover e aumentar a apreciação do público em geral para a química e sobretudo incentivar o interesse dos jovens sobre esta disciplina que desde o século XIX se afirmou como a ciência central. Apenas na química é possível encontrar intersecções de todas as outras ciências fundamentais como a física, a matemática e a biologia, e mais do que fazer a ponte entre elas, a química é o ponto de confluência de todas. Por vezes, na pressa do dia-a-dia tendemos a deixar de nos aperceber como a química está presente à nossa volta, desde a roupa que vestimos, aquilo que comemos até ao sítio onde trabalhamos. É impossível conceber o nosso modo de vida actual sem a intervenção da química e contudo na maior parte das vezes não pensamos nisso.

Além da representação nacional assegurada pela $S P Q$, a rede IYC conta já com cerca de 20 contribuições individuais que cobrem geograficamente Portugal de Norte a Sul, mostrando o compromisso implícito de vários químicos portugueses (membros ou não da $\mathrm{SPQ}$ ) com os princípios deste projecto.

Na preparação para a celebração do IYC 2011, a SPQ tem recebido inúmeras consultas sobre a possibilidade de apoiar as mais variadas acções. $E$ tendencialmente pretendemos dar cobertura a todas elas, na medida das nossas possibilidades e salvaguardando o património da SPQ.

Estamos a ultimar um portal dedicado à iniciativa onde iremos colocar todas as acções planeadas e em curso. Estamos a elaborar uma Comissão Nacional, encabeçada por um dos nossos químicos mais eminentes, ca- paz de conferir às nossas acções a dignidade e a consistência que elas merecem. Desde já podemos adiantar que além de algumas actividades já anunciadas e que seguramente irão tomar forma nos próximos meses, teremos um programa de exposições, palestras, experiências a nível local e a nível global, acções colectivas com muitos jovens, bastantes materiais interactivos na rede global, demonstrações interactivas ao vivo em laboratórios escolares, universitários e de outras instituições de pesquisa e desenvolvimento.

Para reforçar este plano vamos sempre que possível associar à celebração do

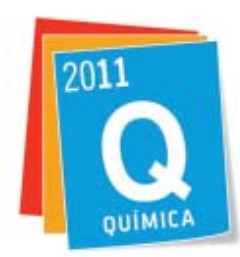

\section{Ano Internacional da QUÍMICA 2011}

IYC uma outra que nos é muito cara e que nos acompanhará durante grande parte de 2011 e 2012: a celebração do Centenário - a SPQ faz 100 anos em Dezembro de 2011.

Estes 100 anos fazem da SPQ uma das mais antigas, mas também das maiores e mais activas associações científicas nacionais, sendo inegavelmente uma instituição idónea e respeitada não só a nível nacional mas também a nível europeu e até mundial. E não se chega a este ponto sem a necessária capacidade de renovação, redescoberta e mesmo reinvenção que só se adquire quando o sangue novo se junta à experiência dos seus mais respeitados membros. Ainda recentemente durante a aber- tura do $2^{\circ}$ Encontro de Químicos Jovens Portugueses (2PYChem) pude expressar publicamente o apreço da SPQ por este grupo que representa sem dúvida algo de muito valioso no seu património - uma promessa de futuro.

Nos tempos actuais em que uma das marcas mais características da sociedade é, de forma irónica, a sua descaracterização, mesmo a sua desorientação, fruto de um pressão desmedida em objectivos quantificáveis, é normal um jovem questionar-se sobre o porquê de associar-se à SPQ. Não raras vezes, a resposta está num objectivo de curto prazo, ou na influência de um professor, ou mesmo, na passagem, quando era ainda mais jovem, pelas Olimpíadas de Química. Há alguns anos a SPQ distribuiu uma brochura sobre 7 razões para ser sócio da SPQ que ainda circula (e que pode ser obtida a pedido junto do nosso secretariado). Há mais anos atrás, era eu também jovem estudante de Engenharia Química no IST, quando decidi fazerme sócio. Tenho a certeza que não pensei em nenhuma das tais 7 razões específicas. Creio que era sobretudo a vontade de fazer parte de algo maior que eu próprio e a excitação de poder participar naquele universo misterioso da química. Grande parte dessa excitação ainda se mantém e gostaria que a SPQ de hoje conseguisse de igual modo motivar os jovens a entrar neste universo. Por essa razão, fizemos disso um dos nossos objectivos para o Ano Internacional da Química.

Estamos a planear imensos eventos para celebrar o IYC 2011. Convido-os a passarem regularmente pelo nosso portal, seguirem o nosso boletim e a nossa newsletter, informarem-se das nossas actividades, envolverem-se com a nossa Sociedade Portuguesa de Química e através dela com o resto da comunidade química global.

Joaquim Luís Faria
Secretário-Geral SPQ
www.spq.pt
www.spq.pt 